\title{
Platinum-group mineralization at the margin of the Skaergaard intrusion, East Greenland
}

\author{
Jens C. Ø. Andersen ${ }^{1}$ - Gavyn K. Rollinson ${ }^{1}$ - Iain McDonald ${ }^{2}$ - Christian Tegner ${ }^{3}$ • \\ Charles E. Lesher ${ }^{3,4}$
}

Received: 28 June 2016 / Accepted: 5 December 2016 / Published online: 10 January 2017

(C) The Author(s) 2017. This article is published with open access at Springerlink.com

\begin{abstract}
Two occurrences of platinum-group elements (PGEs) along the northern margin of the Skaergaard intrusion include a sulfide-bearing gabbro with slightly less than $1 \mathrm{ppm}$ $\mathrm{PGE}+\mathrm{Au}$ and a clinopyroxene-actinolite-plagioclase-biotiteilmenite schist with 16 vol\% sulfide and $1.8 \mathrm{ppm}$ PGE $+\mathrm{Au}$. Both have assemblages of pyrrhotite, pentlandite, and chalcopyrite typical for orthomagmatic sulfides. Matching platinumgroup mineral assemblages with sperrylite $\left(\mathrm{PtAs}_{2}\right)$, kotulskite $\left(\mathrm{Pd}(\mathrm{Bi}, \mathrm{Te})_{1-2}\right)$, froodite $\left(\mathrm{PdBi}_{2}\right)$, michenerite $(\mathrm{PdBiTe})$, and electrum (Au,Ag) suggest a common origin. Petrological and geochemical similarities suggest that the occurrences are related to the Skaergaard intrusion. The Marginal Border Series locally displays Ni depletion consistent with sulfide fractionation, and the PGE fractionation trends of the occurrences are systematically enriched by $10-50$ times over the chilled margin. The PGE can be explained by sulfide-silicate immiscibility in the Skaergaard magma with $R$ factors of 110 220. Nickel depletion in olivine suggests that the process
\end{abstract}

Editorial handling: M. Fiorentini

Electronic supplementary material The online version of this article (doi:10.1007/s00126-016-0707-3) contains supplementary material, which is available to authorized users.

Jens C. Ø. Andersen

J.C.Andersen@exeter.ac.uk

1 Camborne School of Mines, University of Exeter, Penryn Campus, Tremough, Penryn TR10 9FE, UK

2 School of Earth and Ocean Sciences, Cardiff University, Main Building, Park Place, Cardiff CF10 3AT, UK

3 Department of Geocience, Aarhus University, Høegh-Guldbergs Gade 2, 1672, 8000 Aarhus C, Denmark

4 Geology Department, University of California, One Shields Avenue, Davis, CA 95616-8605, USA occurred within the host cumulate, and the low $R$ factors require little sulfide mobility. The sulfide assemblages are different to the chalcopyrite-bornite-digenite assemblage found in the Skaergaard Layered Series and Platinova Reef. These differences can be explained by the early formation of sulfide melt, while magmatic differentiation or sulfur loss caused the unusual sulfide assemblage within the Layered Series. The PGEs indicate that the sulfides formed from the Skaergaard magma. The sulfides and PGEs could not have formed from the nearby Watkins Fjord wehrlite intrusion, which is nearly barren in sulfide. We suggest that silicate-sulfide immiscibility led to PGE concentration where the Skaergaard magma became contaminated with material from the Archean basement.

Keywords Skaergaard intrusion · Platinum-group elements · Greenland

\section{Introduction}

The discovery of the Platinova Au-Pd Reef in the Skaergaard intrusion during 1986 was a surprise to many geologists (Bird et al. 1991). It was remarkable how a very large Au-Pd resource could have remained undetected for more than 50 years in what was considered to be one of the most intensely studied layered intrusions on Earth. It was equally intriguing how high-grade reefs could develop in a small, highly evolved intrusion very unlike the large Precambrian mafic-ultramafic complexes (Bushveld, Stillwater, the Great Dyke) that host the traditional resources of platinum-group elements (PGEs). Subsequent discoveries in other evolved intrusions radically changed the view of where PGE mineralization may occur and led to the recognition of a new class called "Skaergaard-type PGE deposits" by Prendergast (2000). These deposits are stratiform, develop much higher in the igneous stratigraphy than the traditional 
resources (such as the Merensky and J-M reefs), and have low sulfur, nickel, and chromium. They are considered either to form in response to sulfide saturation following extensive differentiation of S-poor, PGE-rich tholeiitic magmas (Miller and Andersen 2002; Momme et al. 2002; Holwell and Keays 2014) or by selective metal partitioning in systems with immiscible silicate magmas (Nielsen et al. 2015).

Here, we report two new occurrences of PGEs to the north of the known exposures of the Skaergaard intrusion. They have recently been uncovered by glacial retreat and may originally have been at the basal margin of the intrusion. The occurrences are near exposures of the Watkins Fjord wehrlite, a small plug-like intrusion that Kays and McBirney (1982) identified as the source for abundant picrite xenoliths in the Skaergaard Marginal Border Series (MBS). Our aim is to describe the occurrences and establish if they represent previously unrecognized mineralization along the Skaergaard margin or whether they formed in relation to the Watkins Fjord wehrlite plug.

\section{Geological setting}

The Paleogene East Greenland Igneous Province is one of the world's largest flood basalt provinces and one of the most prospective regions for PGE (Andersen et al. 2002). Stratiform Au and PGE-rich layers formed in the Skaergaard intrusion (Bird et al. 1991; Andersen et al. 1998; Nielsen et al. 2015) and the Kap Edvard Holm complex (Bird et al. 1995; Arnason and Bird 2000), while marginal and contact style mineralization occurred in the Nordre Aputitêq intrusion (Arnason 1995), the Kruuse Fjord complex (Arnason et al. 1997), the Miki Fjord Macrodyke (Arnason 1995), and the Togeda Macrodyke (Holwell et al. 2012). The mineralization is considered to be related to the formation of sulfide within the host silicate magmas, either through fractional crystallization (in the Skaergaard intrusion, Andersen et al. 1998), magma mixing (in the Kap Edvard Holm complex, Bird et al. 1995), or in response to contamination (in the macrodykes, Holwell et al. 2012). By far, the richest and most extensive resource is the Platinova Reef in the Skaergaard intrusion, where two separate zones are inferred at $106.8 \mathrm{Mt}$ with $1.68 \mathrm{ppm} \mathrm{Au}$ and $103.5 \mathrm{Mt}$ with $1.91 \mathrm{ppm}$ Pd (Platina Resources Ltd 2008). This resource is also the most enigmatic, as it shows evidence for PGE mineralization in a magma chamber with immiscible iron-rich and iron-poor silicate liquids (Nielsen et al. 2015).

An Archean metamorphic basement sequence borders the 56-Ma-old (Wotzlaw et al. 2012) Skaergaard intrusion to the north (Fig. 1). The basement is structurally beneath the intrusion and consists of strongly folded and foliated orthogneisses with bands and lenses of ultramafics, amphibolites, quartzites, and sillimanite-bearing garnet-biotite schists (Kays et al.
1989). Orthogneisses range from diorite and granodiorite to tonalite-trondhjemite-granite and are locally migmatitic. Ultramafics include olivine-pyroxene hornblendites, pyroxene-hornblende, and olivine-hornblende peridotites, while mafic units are hornblende-rich tonalites and diorites (Kays et al. 1989).

Approximately $1 \mathrm{~km}$ to the north of the Skaergaard intrusion, the basement includes a small plug-like ultramafic intrusion, the Watkins Fjord wehrlite. The plug was first described by Kays and McBirney (1982), who considered it to have been the source of abundant picrite blocks in the Marginal Border Series of the Skaergaard intrusion. Although Kays and McBirney (1982) did not specifically address the age, the intrusion was mapped as Precambrian by McBirney (1989). The plug is extensively covered by glacial till and exposed only in outcrops across an area of $600 \times 800 \mathrm{~m}$ on a small peninsula that protrudes into Watkins Fjord to the north of the Skaergaard intrusion (Fig. 1). The outcrops delineate a roughly oval shape to the plug, and apart from thin fractures filled with serpentine minerals, the rocks are unaltered and undeformed. The unfoliated nature and lack of hornblende contrast to the highly elongate, folded, and foliated ultramafic bands in the basement succession. These characteristics, along with isotopic similarities to other ultramafic plugs that are exposed along the Kangerlussuaq Fjord, suggest that the plug is more likely of Palaeogene age (Stewart and DePaolo 1990; Holm 1991; S. Bernstein, personal communication, 1993).

The Skaergaard intrusion was emplaced along the unconformity that separates the Precambrian basement from a thin succession of Cretaceous to Paleocene sediments and the Paleocene to Eocene East Greenland flood basalts. The intrusion represents the crystalline products of evolved Ti-rich tholeiitic magma that fractionated through extreme closed system magmatic differentiation. The Marginal Border Series formed along the walls, the Layered Series on the floor, and the Upper Border Series below the roof of the intrusion (Wager and Brown 1968; Irvine et al. 1998). To the north, the Skaergaard intrusion has a well-defined intrusive contact with a meter-wide chilled margin against the basement. The margin is here followed inwards by a 50 to 70 -m-wide zone of the MBS with abundant picrite blocks in a matrix of mediumgrained gabbro. The picrite blocks occupy $35-50$ vol\% of this zone and are intermixed with less abundant blocks of hercynite-bearing metasediment, gneiss, dolerite, and hornfelsed basalt (Wager and Brown 1968; Irvine et al. 1998). Kays and McBirney (1982) suggested that the picrite blocks form a continuous compositional succession with the Watkins Fjord wehrlite and that their more evolved compositions developed through equilibration with the Skaergaard magma. The block-rich zone is followed by the crossbedded belt that defines the transition to the Layered Series.

The most primitive cumulates in the Layered Series have plagioclase and olivine on the liquidus. These minerals are 

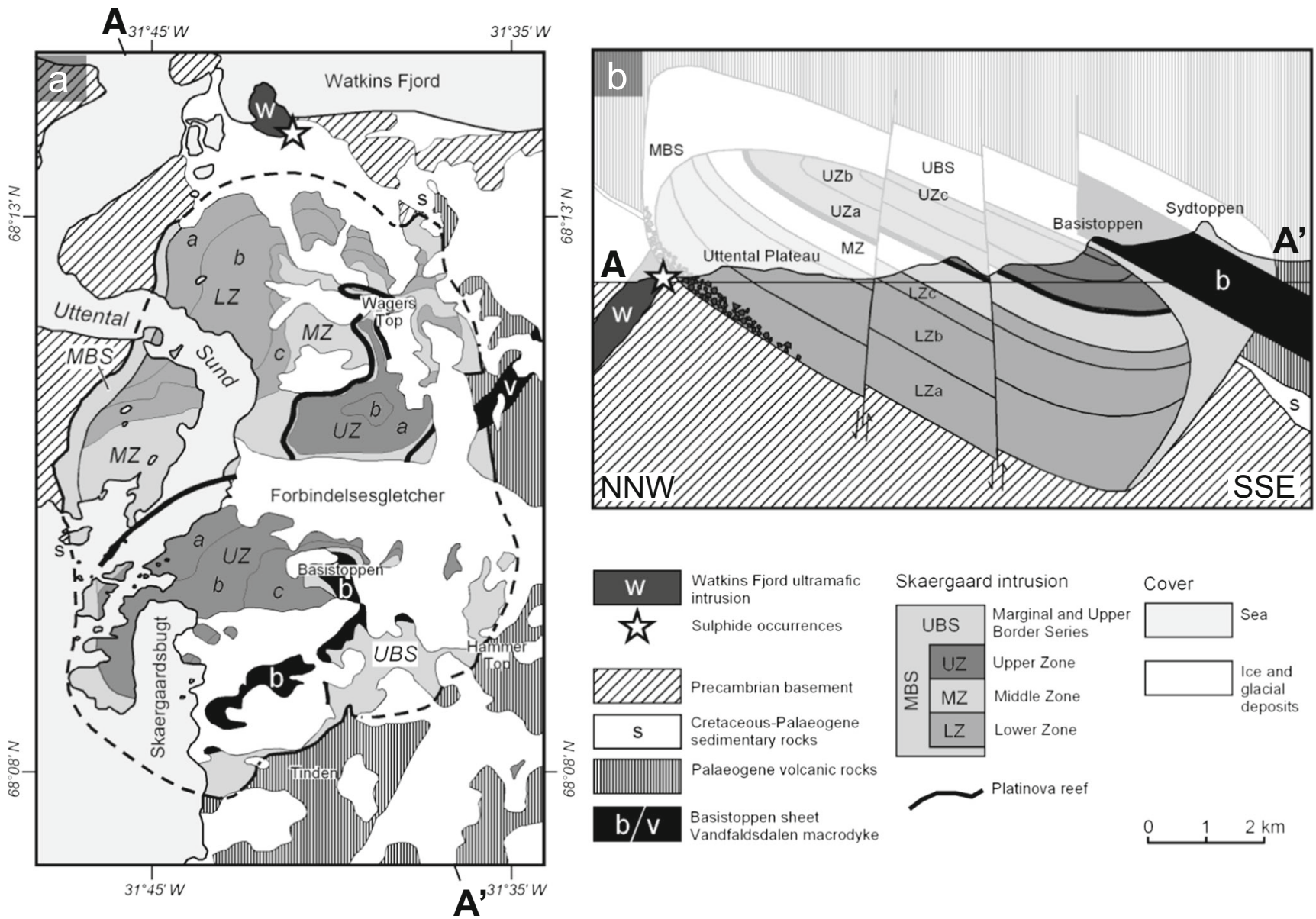

Fig. 1 Geological map of the Skaergaard intrusion and Watkins Fjord wehrlite (after McBirney 1989). Note that the actual projection of the wehrlite intrusion at depth is inferred

successively joined by augite, ilmenite, and magnetite up through the Lower Zone. The Middle Zone is characterized by the peritectic replacement of olivine by pigeonite, while the Upper Zone sees the re-appearance of olivine and subsequently apatite and ferrobustamite (Wager and Brown 1968; Lindsley et al. 1969). The Platinova Reef formed toward the top of Middle Zone at around $1600 \mathrm{~m}$ in the Layered Series stratigraphy. This is much later than the appearance of cumulus magnetite and ilmenite - a feature that sets it apart from the traditional PGE resources in the Bushveld and Stillwater complexes where mineralization took place near the transition from ultramafic to mafic rocks.

\section{Analytical techniques}

The samples were prepared into polished blocks and thin sections at Camborne School of Mines (CSM), University of Exeter. Sulfide concentrates were prepared by gentle crushing in a tungsten carbide mill until all materials passed through a $250-\mu \mathrm{m}$ sieve. The powdered materials were sieved and the 63-125 and 125-250 $\mu \mathrm{m}$ fractions processed by the HS- 11 hydroseparator (Rudashevsky et al. 2002) at Camborne School of Mines to produce the final concentrates. These concentrates were mounted into polished blocks for optical examination and electron probe microanalysis.

Mineral abundances and associations were determined with the QEMSCAN® 4300 at CSM using field scan and trace mineral search routines. Field scans were produced with a $10-\mu \mathrm{m}$ point grid, and the analyses refer to a modified LCU5 species identification protocol (Gottlieb et al. 2000; Pirrie et al. 2004) that is customized to the materials. Data are based on between six and seven million energy-dispersive X-ray analyses on each polished block and thin section. Mineral abundances are reported by volume with weight proportions calculated by the use of specific gravity; associations are reported as relative grain boundary lengths (in percent).

Mineral compositions were determined with the JEOL JXA-8200 electron probe microanalyzer at CSM using a 15$30 \mathrm{nA}$ electron beam (100 nA for $\mathrm{NiO}$ in olivine) accelerated to $15 \mathrm{kV}$ with reference to natural mineral standards, apart from the PGEs that refer to pure metal standards. X-ray signals were corrected for matrix effects using the phi-rho-Z method (Armstrong 1995) implemented by Paul Carpenter. 
Whole-rock platinum-group elements were analyzed by nickel sulfide fire assay and ICP-MS at Cardiff University following the method of Huber et al. (2001). The PGE tenors are calculated from the geochemical data (total PGE $+\mathrm{Au}$ ) with the sulfide abundances measured by QEMSCAN. The $R$ factors were calculated by the following equation:

$R=\frac{T_{\mathrm{PGE}+\mathrm{Au}}}{C_{\mathrm{PGE}+\mathrm{Au}}^{\mathrm{CM}}}$

where $R$ is the silicate-sulfide mass ratio (the $R$ factor), $T_{\mathrm{PGE}}+$ $\mathrm{Au}$ is the combined tenor of PGE and $\mathrm{Au}$ (in ppb), and $C_{\mathrm{PGE}+\mathrm{Au}}^{\mathrm{CM}}$ is the concentration of PGE and Au in the Skaergaard chilled margin (in ppb, reported by Momme 2000).

\section{Geological and mineralogical relations}

The PGE occurrences (Figs. 1 and 2) are located $300 \mathrm{~m}$ southeast of the known exposures of the Watkins Fjord wehrlite and $1300 \mathrm{~m}$ to the north of the exposures of the Skaergaard intrusion as mapped by McBirney (1989). The physical connections to these intrusions are tenuous because of extensive moraine cover. Figure 3 provides the key to the mineral maps presented in Figs. 4, 5, and 8.

\section{Platinum-group element occurrences}

The northernmost occurrence (sample WW08, Fig. 2a, Table 1) is hosted by undeformed gabbro that displays weak subhorizontal lamination and includes 2-m-long units of comb-layered crescumulate (Fig. 2a) along with scattered, up to 0.5 -m-wide leucogabbro blocks (Fig. 2a, b). The gabbro consists of olivine + clinopyroxene orthocumulates with interstitial plagioclase and orthopyroxene (Fig. 4a). The crescumulate units each evolve from a leucogabbroic base to a mesogabbroic top. Sulfides are distributed throughout the cumulate, including these crescumulate units. The collected sample carries 4.4 vol\% (5.8 wt\%) disseminated Fe-Cu-Ni sulfide (Fig. 4b) as well as minor ilmenite and biotite. Cumulus olivine is relatively variable at $\mathrm{Fo}_{76-70}$. The most calcic
Fig. 2 Photos of the PGEbearing outcrops and the Skaergaard northern contact. a PGE-bearing cumulate with included blocks and two crescumulate units. The position of sample WW08 is indicated by the box. b Small, angular leucogabbro block in same outcrop as a. c Metamorphic schist with disseminated PGEbearing sulfides. A broad zone with $2-5 \%$ sulfide surrounds a pocket with $15 \%$ sulfide. Sample WW09 was collected from the sulfide-rich pocket, as indicated by the box. $\mathbf{d}$ Cut and polished section through sample WW09 showing the distribution of sulfide within the host schist. e The northern margin of the Skaergaard intrusion against the Precambrian basement around $1.5 \mathrm{~km}$ to the west of the PGEbearing outcrops. The $20^{\circ}$ dip of the contact toward the south is a result of coastal flexure after the emplacement and crystallization of the Skaergaard magma
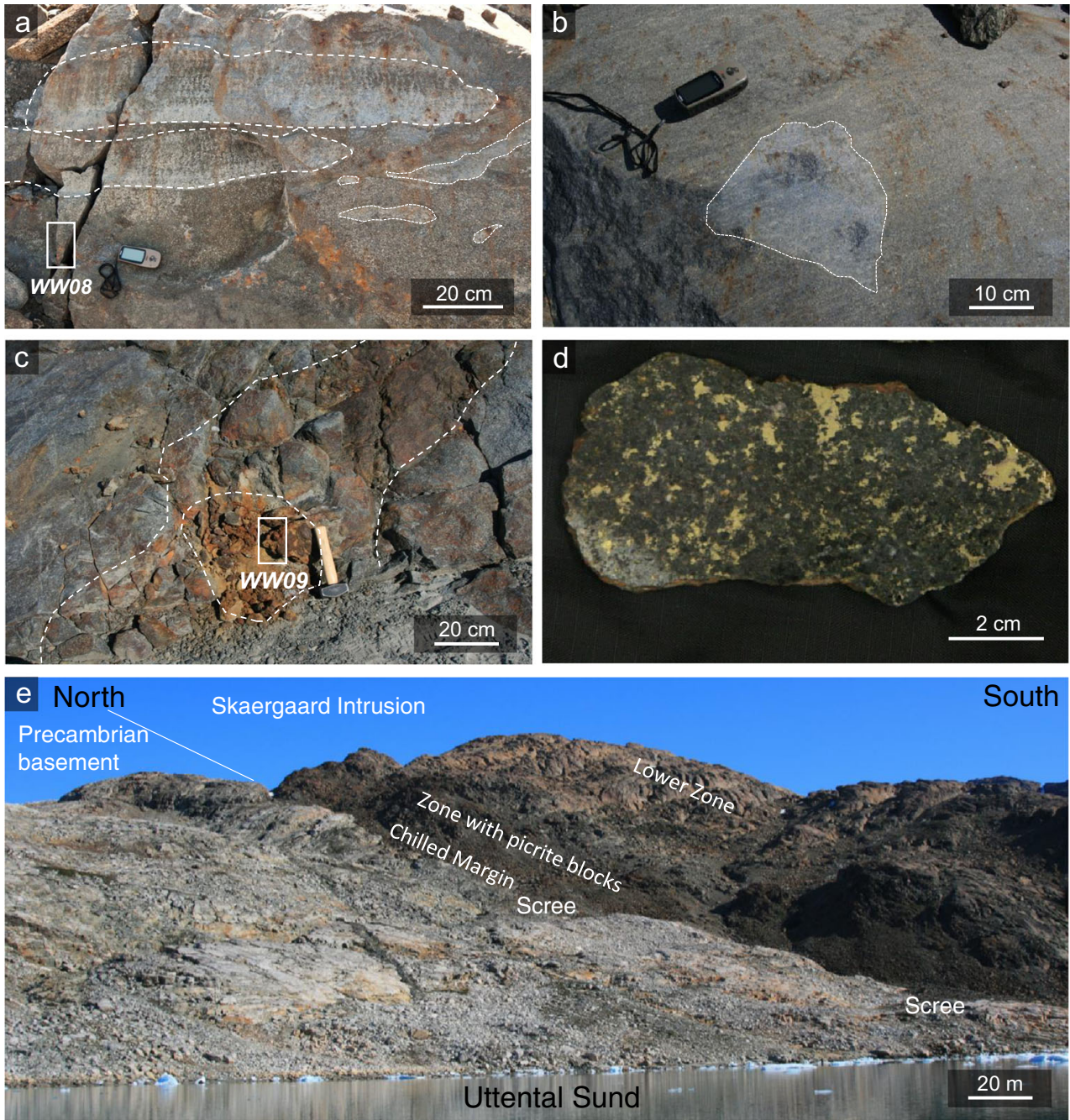
Table 1 Mineral abundances and platinum-group mineral (PGM) associations

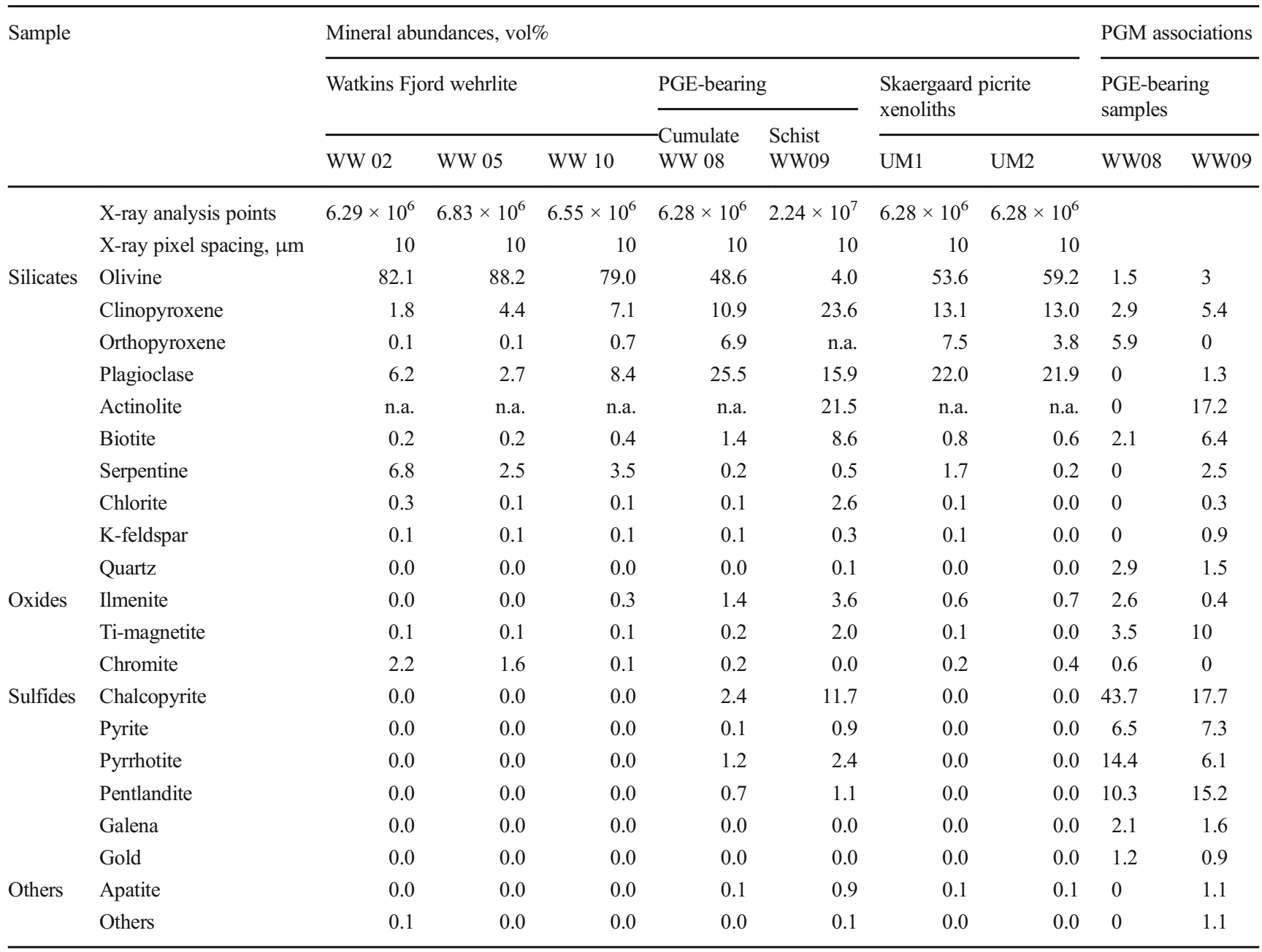

Data from QEMSCAN. Mineral abundances based on field scans; PGM associations based on trace mineral searches

n.a. not analyzed

interstitial plagioclase has $\mathrm{An}_{67}$. The gabbro carries $990 \mathrm{ppb}$ PGE (Electronic Supplement Table 1).

The second occurrence, around $50 \mathrm{~m}$ further to the south (sample WW09, Fig. 2c, d, Table 1), is a clinopyroxeneactinolite-plagioclase-biotite-ilmenite schist (Fig. 4c) that carries significant apatite $(0.9$ vol\% $)$ and titanomagnetite (1.4 vol\%) and up to 16 vol\% (20 wt $\%$ ) Fe-Cu-Ni sulfide (Fig. 4d). The abundant clinopyroxene combined with a lack of quartz, K-feldspar, and garnet suggests that the schist formed from a mafic igneous protolith. Orthopyroxene has $\mathrm{Mg} /(\mathrm{Mg}+\mathrm{Fe})$ of 33-42; plagioclase has $\mathrm{An}_{25}$, and apatite has $\mathrm{F} /(\mathrm{F}+\mathrm{Cl})$ of $93-97$ at $\%$. The rock carries $1760 \mathrm{ppb}$ PGE (Electronic Supplement Table 1).

\section{The Watkins Fjord wehrlite}

The Watkins Fjord wehrlite plug consists of mesocumulates of olivine (79-88 vol\%) \pm chromite $(<2$ vol\%) with interstitial plagioclase (2-8 vol\%), poikilitic clinopyroxene (1-7 vol\%), and locally also with poikilitic orthopyroxene $(<1 \mathrm{vol} \%)$ and/ or ilmenite $(<0.5$ vol\%) (Fig. 5a, b, Table 1$)$. The cumulates are unaltered and show no evidence for tectonic deformation. Only very minor serpentinization occurred along fractures in the rocks. The wehrlite shows little mineralogical variation with only minor differences in the relative abundances of interstitial minerals across the plug. The whole-rock $\mathrm{Mg} /(\mathrm{Mg}+$ $\mathrm{Fe}$ ) is $76-78$ at $\%$, and the total PGE varies from 27 to $40 \mathrm{ppb}$ (Electronic Supplement Table 1).

\section{The northern margin of the Skaergaard intrusion}

The northern margin represents the structurally lowest exposures and most primitive rocks of the Skaergaard intrusion. The contact is visible in outcrop around $1.5 \mathrm{~km}$ to the west on Uttental Plateau (Fig. 2e). Here, the margin dips around $20^{\circ}$ to the south consistent with a subhorizontal orientation at the 


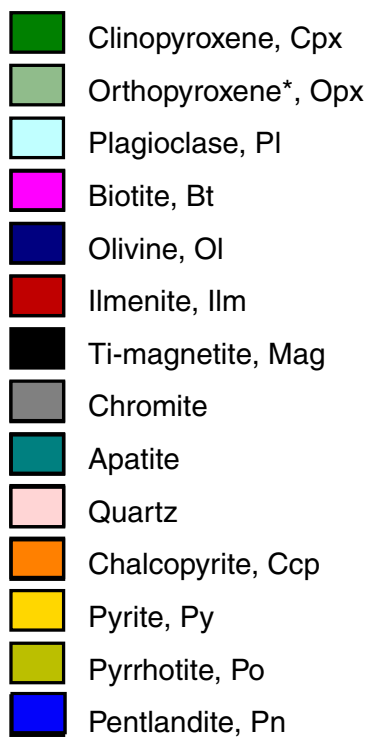

Fig. 3 Key to the mineral distribution maps (Figs. 4 and 5) and mineral associations (Fig. 8). Mineral abbreviations follow Whitney and Evans (2010). The asterisk indicates that orthopyroxene in the Skaergaard intrusion is mostly inverted pigeonite

base of the intrusion prior to rift-related collapse of the East Greenland continental margin (coastal flexure, Nielsen and Brooks 1981). The Skaergaard chilled margin is followed inward by the zone with abundant picrite xenoliths which is succeeded by the cross-bedded belt that defines the transition to the Layered Series. The chilled margin is a two-pyroxene dolerite that is locally olivine-phyric (Fig. 5c). Olivine has compositions of $\mathrm{Fo}_{57-60}$. At the northern margin of the intrusion, the characteristic lithologies of the outermost parts of the MBS (the Tranquil Division) along the eastern and western margins of the intrusion are largely missing. The abundant picrite blocks and other xenoliths found along this margin are distributed within plagioclase-olivine orthocumulates with poikilitic clinopyroxene that locally display phase segregation and crude layering as well as very rare pegmatitic domains. Olivine has $\mathrm{Fo}_{70-71}$ and plagioclase $\mathrm{An}_{72-71}$. Inward from the zone with blocks, the cross-bedded belt marks the transition to the Layered Series. The lowermost plagioclase-olivine cumulates (Fig. 5d) display modal banding in an orientation that would originally have been subhorizontal. Augite appears as a cumulus mineral after around $220 \mathrm{~m}$ of stratigraphy (Fig. 5e), and iron-titanium oxides become abundant at around $740 \mathrm{~m}$ (Fig. 5f). Cumulus olivine at the base of the Layered Series has $\mathrm{Fo}_{67}$ and plagioclase $\mathrm{An}_{66}$.

Picrite blocks in the Marginal Border Series are olivineplagioclase cumulates with interstitial clinopyroxene and orthopyroxene (Fig. 5g-h). Olivine forms large euhedral crystals, while cumulus plagioclase crystals are much smaller and interspersed with the interstitial pyroxenes. Although Kays and McBirney (1982) suggested that the blocks were derived from the Watkins Fjord wehrlite, the blocks are distinctly different in their cumulus mineral assemblages and compositions. Their assemblage of olivine and plagioclase is more evolved than the olivine (+chromite) assemblage of the wehrlite plug, but the composition of olivine $\left(\mathrm{Fo}_{81-79}\right)$ in the blocks is slightly more primitive than the wehrlite $\left(\mathrm{Fo}_{79-78}\right)$.
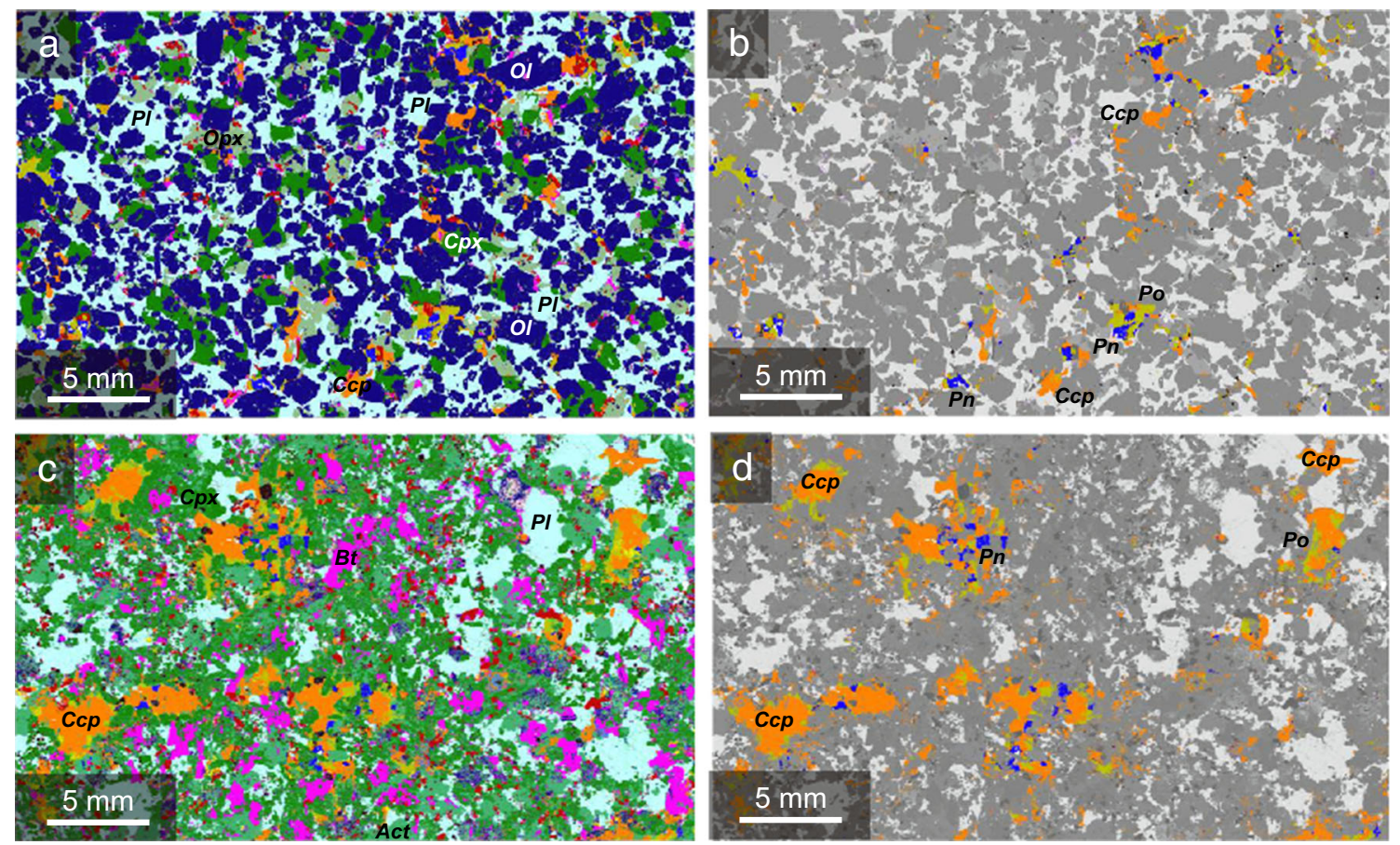

Fig. 4 False color mineral distribution maps of the two sulfide-bearing samples produced with the QEMSCAN. a, b Sulfide-bearing cumulate (WW08). $\mathbf{c}, \mathbf{d}$ Sulfide-bearing schist (WW09). Figures b and $\mathbf{d}$ highlight the sulfide minerals; silicates and oxides have been grayed out for clarity 

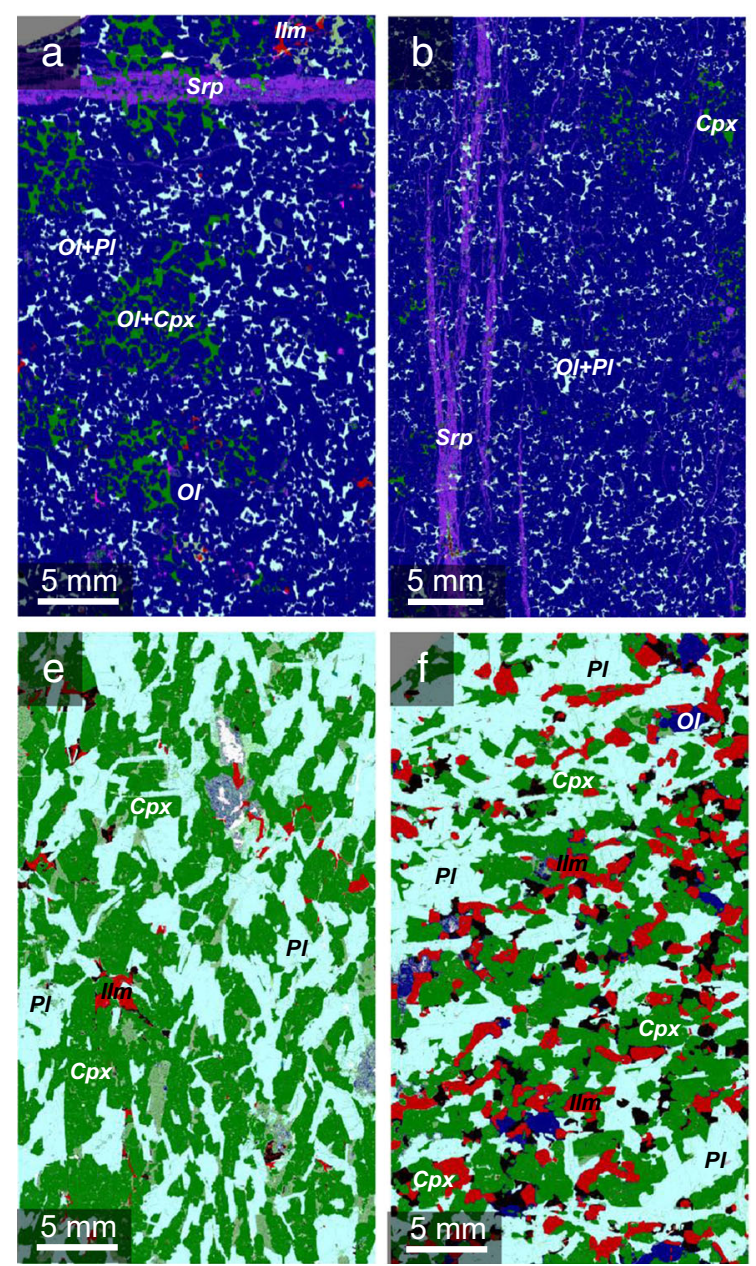

Fig. 5 False color mineral distribution maps produced with the QEMSCAN. a, b Samples from the Watkins Fjord wehrlite intrusion. c The Skaergaard chilled margin. d-f Cumulates from the Lower Zone (a, b,

\section{Nickel in olivine}

Nickel in olivine is a well-established indicator for equilibration of olivine with sulfide melt in mafic magmas (e.g., Fleet et al. 1981; Brenan 2003). Within the Layered Series, nickel in olivine defines a well-constrained trend of decreasing $\mathrm{NiO}$ with decreasing forsterite content as expected from silicate fractionation (Fig. 6; Table 2; data from Park et al. 2010 and our analyses). Olivine in the chilled margin has $\mathrm{Fo}_{57-60}$ and $0.16-0.18 \mathrm{wt} \% \mathrm{NiO}$. The $\mathrm{NiO}$ is similar to the most primitive rocks from the Marginal Border Series, but the olivine crystals are poorer in Fo (more $\mathrm{Fe}$-rich) indicative of local supercooling along the margin (Wager and Brown 1968). Inward from the chilled margin, rocks from the MBS have olivine with $\mathrm{Fo}_{68-71}$. While olivine in some samples has $0.14-0.18 \mathrm{wt} \% \mathrm{NiO}$, as would be expected, other samples are substantially depleted with only $0.03-0.06 \mathrm{wt} \% \mathrm{NiO}$.

The picrite blocks and Watkins Fjord wehrlite fall along a continuation of the Skaergaard trend to higher $\mathrm{NiO}$ and $\mathrm{Fo}$ reflecting their relatively unevolved nature. Olivine in the
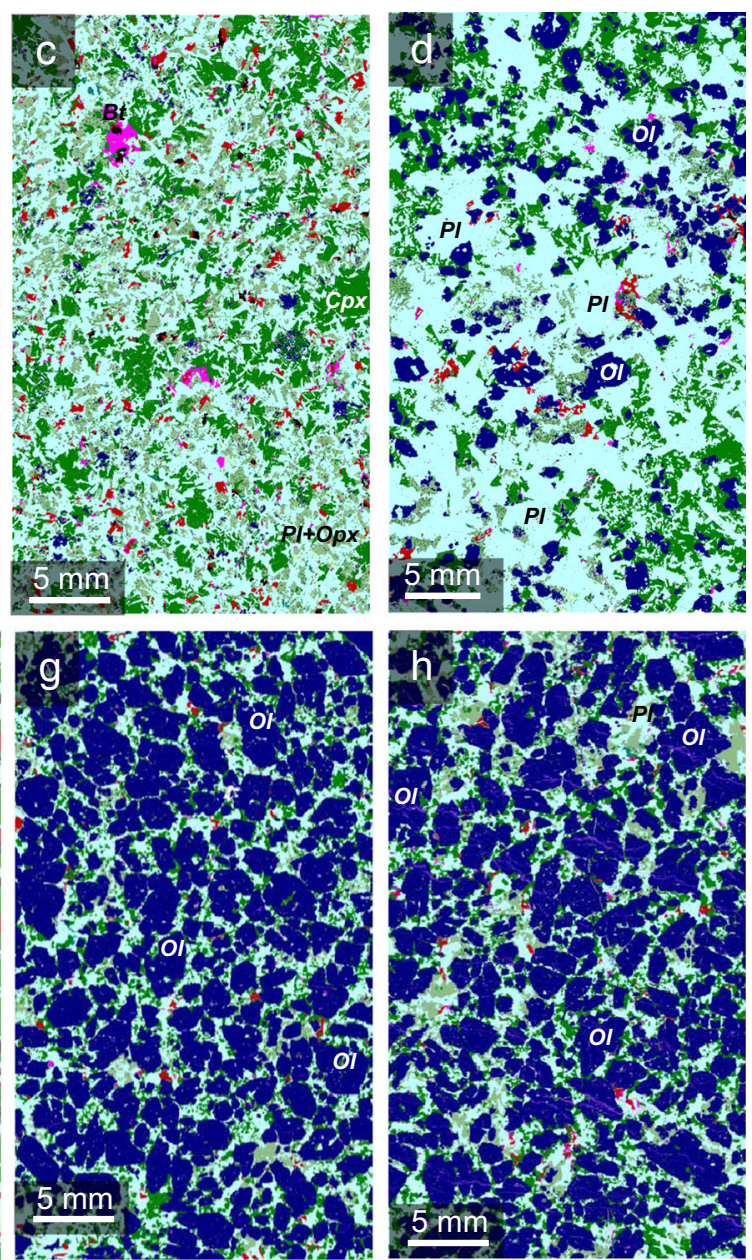

and c) of the Skaergaard Layered Series. g, h Picrite blocks from the Skaergaard Marginal Border Series

wehrlite plug is nearly constant in composition at $\mathrm{Fo}_{79-77}$ and $0.24-0.28 \mathrm{wt} \% \mathrm{NiO}$. However, some olivine has anomalously low $\mathrm{NiO}$ indicative of equilibration with sulfide melt. The picrite blocks have slightly less evolved olivine at $\mathrm{Fo}_{81-79}$ with $0.27-0.34$ wt $\%$ NiO.

Olivine in the PGE-bearing gabbro falls between the Skaergaard trend and the wehrlite plug. With a wide compositional range of $\mathrm{Fo}_{76-70}$ and containing $0.25-0.13 \mathrm{wt} \% \mathrm{NiO}$, the olivine is more evolved and compositionally much more variable than the wehrlite plug. The variable Fo content suggests a mixed population, and the widely variable $\mathrm{NiO}$ contents are consistent with equilibration with sulfide melt prior to or during crystallization.

\section{Sulfide and PGE mineralization}

Sulfides in both occurrences are dominated by chalcopyrite with less pyrrhotite and pentlandite and minor pyrite (Table 1). In the gabbro, 50 vol\% of the sulfide is chalcopyrite and 
Fig. 6 Variations in Ni in olivine in the Skaergaard intrusion, the Watkins Fjord wehrlite, and the PGE-bearing cumulate. Data from our study and Park et al. (2010, recalculated to $\mathrm{NiO}$ ). The variations can be explained with three principal trends: a silicate fractionation (blue trend), $\mathbf{b}$ supercooling reflected by relatively Fo-poor olivine in the chilled margin (orange trend), and $\mathbf{c}$ sulfide fractionation leading to local depletion of $\mathrm{NiO}$ in the Marginal Border Series, to a lesser extent the Watkins Fjord wehrlite, and notably also in the PGE-bearing cumulate (green trend)

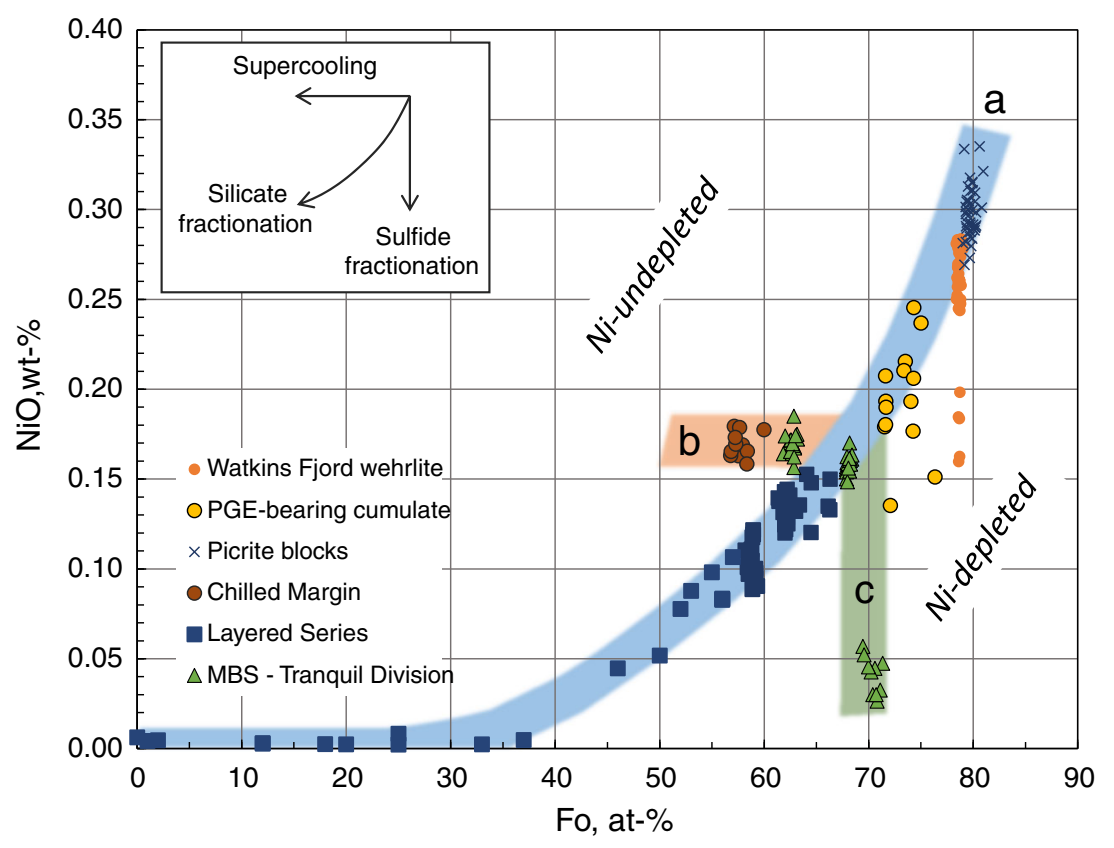

16 vol\% pentlandite, while the schist has 73 vol\% chalcopyrite and only 7 vol\% pentlandite. Platinum-group minerals (PGMs, Fig. 7, Electronic Supplement Table 2) include large $>100-\mu \mathrm{m}$ grains of sperrylite $\left(\mathrm{PtAs}_{2}\right)$, minute $(<10 \mu \mathrm{m})$ grains of kotulskite $\left(\mathrm{Pd}(\mathrm{Bi}, \mathrm{Te})_{1-2}\right)$, froodite $\left(\mathrm{PdBi}_{2}\right)$, michenerite (PdBiTe), electrum (Au,Ag), and rare grains of unnamed $\mathrm{Pd}-$ $\mathrm{Ni}-\mathrm{As}(-\mathrm{Sn})$ minerals with stoichiometries near $(\mathrm{Pd}, \mathrm{Ni}){ }_{15} \mathrm{As}_{9}$ and $\mathrm{Pd}_{4} \mathrm{SnAs}$.

The PGMs are closely associated with sulfides (Table 1, Fig. 8). In the gabbro sample, $77 \%$ of the PGM grain boundary length is shared with sulfide, while the remainder is with silicates and oxides. Only $2 \%$ of the grain boundary length is shared with biotite and none with apatite. The metamorphic hosted occurrence shows a weaker relationship between the PGM and sulfides (48\% of the grain boundary length), while $25 \%$ of the grain boundary length is shared with hydrous silicates (actinolite, biotite, chlorite) and apatite.

The PGEs in both occurrences are dominated by Pd and carry significant Pt. Gold is less significant, while concentrations of $\mathrm{Os}, \mathrm{Ir}, \mathrm{Ru}$, and $\mathrm{Rh}$ are all below $10 \mathrm{ppb}$ (Electronic Supplement Table 1). Mantle-normalized PGE patterns define steep positive trends that are markedly different to the undifferentiated, flat profiles for the Watkins Fjord wehrlite samples but roughly parallel to samples from the Skaergaard chilled margin (Fig. 9, Nielsen and Brooks 1995; Momme 2000). While the total PGE + Au concentrations are nearly twice as high for the metamorphic hosted PGE (1760 ppb) than the PGE-bearing cumulate (989 ppb), the PGE tenor (total PGE + Au in $100 \mathrm{wt} \%$ sulfide) is higher in the cumulate (17.1 ppm) than the schist $(8.9 \mathrm{ppm})$. Metal ratios are $\mathrm{Cu} /$ $\mathrm{Pd}=1.0 \times 10^{4}$ and $\mathrm{Ni} / \mathrm{Cu}=0.3$ for the gabbro and $\mathrm{Cu} /$ $\mathrm{Pd}=2.6 \times 10^{4}$ and $\mathrm{Ni} / \mathrm{Cu}=0.085$ for the schist. The $\mathrm{Pd} / \mathrm{Ir}$ is nearly identical at 290 , the $\mathrm{Pd} / \mathrm{Pt} 3-5$, while the $\mathrm{Pd} / \mathrm{Au}$ is 10 17. For comparison, the Skaergaard chilled margin has $\mathrm{Cu} / \mathrm{Pd}$ of $2.5-3.5 \times 10^{3}$ and $\mathrm{Ni} / \mathrm{Cu}$ of $1.5-2$, while the $\mathrm{Pd} / \mathrm{Ir}$ is 140 , the $\mathrm{Pd} / \mathrm{Pt} 3-5$, and the $\mathrm{Pd} / \mathrm{Au} 1-35$ (Hoover 1989a; Momme 2000). The Watkins Fjord wehrlite samples have $\mathrm{Cu} / \mathrm{Pd}$ of 6 $10 \times 10^{3}, \mathrm{Ni} / \mathrm{Cu}$ of $25-59, \mathrm{Pd} / \mathrm{Ir}$ of $0.7-2, \mathrm{Pd} / \mathrm{Pt}$ of $0.4-1$, and $\mathrm{Pd} / \mathrm{Au}$ of $7-14$.

\section{Discussion}

Despite the very different host lithologies, the similarities in sulfide and PGE mineralogy and geochemistry strongly suggest that the two occurrences share a common origin. While the undeformed nature of the PGE-bearing cumulate precludes a basement origin, this host could theoretically be related to either the Watkins Fjord wehrlite plug or the Skaergaard intrusion. The schist, in contrast, is clearly a basement lithology, although as we argue below, the sulfides are likely to have been derived from a magmatic source.

\section{Relationship to the Watkins Fjord wehrlite}

Although the occurrences are in closest proximity to the wehrlite, the PGE-bearing cumulate is compositionally and structurally very different. The wehrlite is compositionally very uniform across the plug, and there is no field evidence to suggest an evolution in mineral assemblages or compositions toward this outcrop, as would be expected if they formed part of the same magmatic succession. The difference in olivine compositions between the plug and the PGE-bearing cumulate would require extensive magmatic differentiation, and 
Table 2 Representative olivine analyses

\begin{tabular}{|c|c|c|c|c|c|c|c|c|c|c|c|c|c|}
\hline Lithology & $\begin{array}{l}\text { Chilled } \\
\text { margin }\end{array}$ & $\begin{array}{l}\text { Layered } \\
\text { Series, } \\
\text { LZa } \\
\text { LZa } 1\end{array}$ & $\begin{array}{l}\text { Layered } \\
\text { Series, } \\
\text { LZa } \\
\text { LZa } 2\end{array}$ & $\begin{array}{l}\text { MBS } \\
\text { Tranquil } \\
\text { Division } \\
\text { MBS 1 }\end{array}$ & $\begin{array}{l}\text { MBS } \\
\text { Tranquil } \\
\text { Division } \\
\text { MBS } 2\end{array}$ & $\begin{array}{l}\text { MBS } \\
\text { Tranquil } \\
\text { Division } \\
\text { PF 1 }\end{array}$ & $\begin{array}{l}\text { PGE- } \\
\text { bearing } \\
\text { cumulate } \\
\text { WW08 }\end{array}$ & $\begin{array}{l}\text { Picrite } \\
\text { blocks }\end{array}$ & $\begin{array}{l}\text { Picrite } \\
\text { blocks }\end{array}$ & $\begin{array}{l}\text { Picrite } \\
\text { blocks }\end{array}$ & $\begin{array}{l}\text { Watkins } \\
\text { Fjord } \\
\text { wehrlite } \\
\text { WW02 }\end{array}$ & $\begin{array}{l}\text { Watkins } \\
\text { Fjord } \\
\text { wehrlite } \\
\text { WW05 }\end{array}$ & $\begin{array}{l}\text { Watkins } \\
\text { Fjord } \\
\text { wehrlite } \\
\text { WW10 }\end{array}$ \\
\hline \multicolumn{14}{|c|}{ Mineral compositions, wt $\%$} \\
\hline $\mathrm{SiO}_{2}$ & 36.670 & 37.970 & 36.500 & 37.110 & 37.410 & 38.070 & 37.760 & 38.450 & 38.720 & 38.360 & 38.180 & 38.440 & 38.540 \\
\hline $\mathrm{Al}_{2} \mathrm{O}_{3}$ & 0.007 & 0.010 & 0.008 & 0.002 & 0.003 & 0.018 & 0.015 & 0.013 & 0.000 & 0.004 & 0.011 & 0.034 & 0.005 \\
\hline $\mathrm{FeO}$ & 35.440 & 30.920 & 36.210 & 25.690 & 33.370 & 29.040 & 24.280 & 19.190 & 18.580 & 19.000 & 20.000 & 20.130 & 20.210 \\
\hline $\mathrm{MnO}$ & 0.496 & 0.419 & 0.492 & 0.004 & 0.429 & 0.385 & 0.335 & 0.253 & 0.256 & 0.240 & 0.290 & 0.283 & 0.274 \\
\hline $\mathrm{MgO}$ & 29.820 & 33.870 & 29.090 & 35.480 & 31.140 & 34.430 & 37.830 & 41.550 & 42.420 & 41.970 & 41.420 & 41.460 & 41.200 \\
\hline $\mathrm{CaO}$ & 0.027 & 0.035 & 0.070 & 0.027 & 0.034 & 0.042 & 0.027 & 0.012 & 0.024 & 0.044 & 0.107 & 0.072 & 0.115 \\
\hline $\mathrm{NiO}$ & 0.178 & 0.135 & 0.089 & 0.033 & 0.170 & 0.157 & 0.215 & 0.305 & 0.291 & 0.310 & 0.282 & 0.245 & 0.250 \\
\hline Total & 102.637 & 103.359 & 102.459 & 98.346 & 102.556 & 102.142 & 100.462 & 99.773 & 100.292 & 99.928 & 100.289 & 100.664 & 100.595 \\
\hline \multicolumn{14}{|c|}{ Mineral formulas calculated to 24 oxygen } \\
\hline $\mathrm{Si}$ & 5.945 & 5.965 & 5.950 & 5.989 & 5.996 & 5.999 & 5.932 & 5.940 & 5.930 & 5.916 & 5.897 & 5.913 & 5.929 \\
\hline $\mathrm{Al}$ & 0.001 & 0.002 & 0.002 & 0.001 & 0.001 & 0.003 & 0.003 & 0.002 & 0.000 & 0.001 & 0.002 & 0.006 & 0.001 \\
\hline $\mathrm{Fe}$ & 4.806 & 4.062 & 4.937 & 3.468 & 4.473 & 3.828 & 3.190 & 2.479 & 2.380 & 2.451 & 2.584 & 2.589 & 2.600 \\
\hline $\mathrm{Mn}$ & 0.067 & 0.056 & 0.067 & 0.001 & 0.058 & 0.051 & 0.044 & 0.033 & 0.033 & 0.031 & 0.037 & 0.037 & 0.035 \\
\hline $\mathrm{Mg}$ & 7.208 & 7.931 & 7.071 & 8.537 & 7.441 & 8.089 & 8.859 & 9.568 & 9.685 & 9.649 & 9.535 & 9.506 & 9.449 \\
\hline $\mathrm{Ca}$ & 0.005 & 0.006 & 0.012 & 0.005 & 0.006 & 0.007 & 0.005 & 0.002 & 0.004 & 0.007 & 0.017 & 0.012 & 0.019 \\
\hline $\mathrm{Ni}$ & 0.023 & 0.017 & 0.012 & 0.004 & 0.022 & 0.020 & 0.027 & 0.037 & 0.036 & 0.038 & 0.035 & 0.030 & 0.031 \\
\hline Total & 18.055 & 18.034 & 18.049 & 18.004 & 17.996 & 17.996 & 18.059 & 18.061 & 18.068 & 18.093 & 18.107 & 18.093 & 18.064 \\
\hline Fo, at $\%$ & 60.0 & 66.1 & 58.9 & 71.1 & 62.5 & 67.9 & 73.5 & 79.4 & 80.3 & 79.7 & 78.7 & 78.6 & 78.4 \\
\hline
\end{tabular}

this is at variance with the uniform olivine compositions within the plug. In contrast, the much more variable olivine compositions in the PGE-bearing cumulate suggest that it formed from a relatively large, differentiating body of magma. The included leucogabbro blocks further support that the parental magma was in contact with earlier formed differentiated
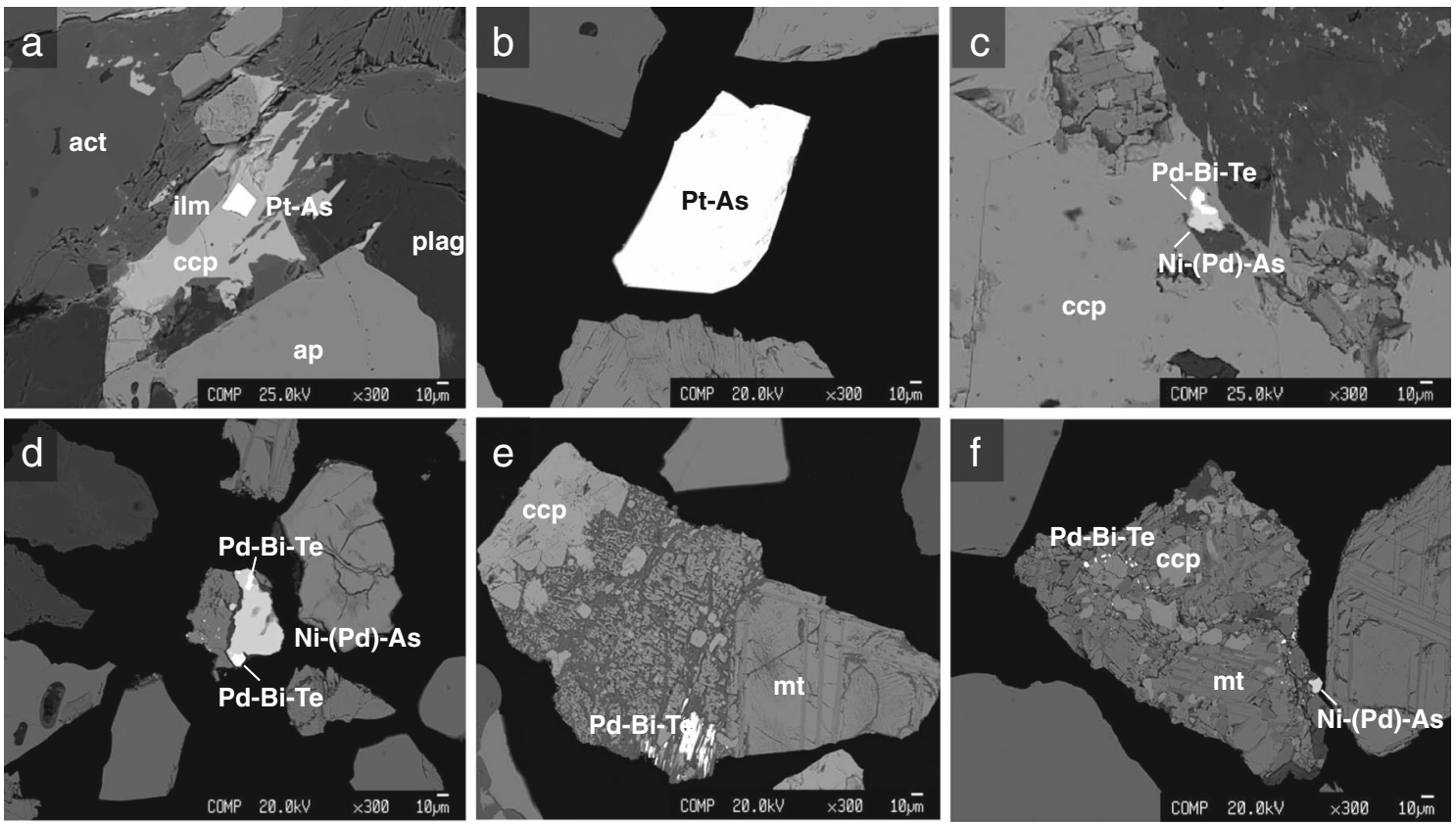

Fig. 7 Platinum-group minerals in the basal sulfide occurences of the Skaergaard intrusion. a Sperrylite $(s)$ crystal enclosed within chalcopyrite $(c c p)$ in an assemblage of actinolite $(a c t)$, biotite $(b t)$, plagioclase $(p l)$, and apatite (ap). b Large, fully liberated grain of sperrylite recovered from

mineral concentrate. $\mathbf{c}$ Minute grains of michenerite $(m)$ in palladian gersdorffite $(g)$. d Michenerite crystals enclosed within fine-grained actinolite-magnetite mix and associated with magnetite $(m t)$ and chalcopyrite 
Fig. 8 Mineral associations (based on cumulative grain boundary length) of PGM and gold with their various host minerals. Minerals considered to be metasomatic are the hydrous silicates (actinolite, biotite, chlorite), quartz, apatite, and $\mathrm{Fe}$ oxides (which locally replace sulfides)
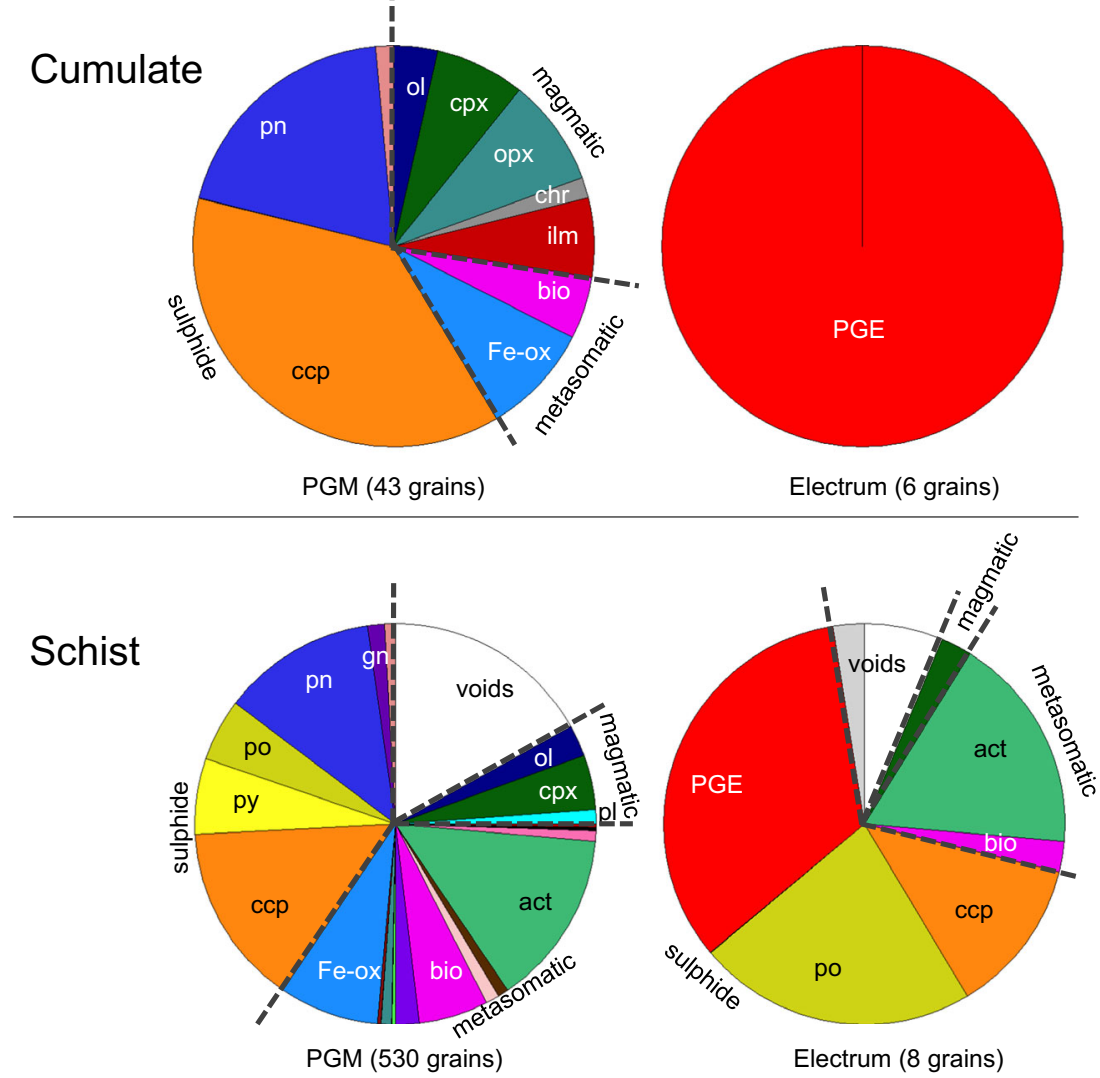

products. These blocks are very different to the primitive olivine + chromite cumulates of the Watkins Fjord wehrlite, and they must have been derived from a magma that crystallized a very different mineral assemblage. As above, this would be expected to involve extensive differentiation, which would be more consistent with a formation in the much larger Skaergaard intrusion

The strongly fractionated PGE in the cumulate also greatly contrasts to the unfractionated PGE within the wehrlite. Although sulfide liquids are generally expected to carry Pt, $\mathrm{Pd}$, and $\mathrm{Au}$ in preference to $\mathrm{Ir}, \mathrm{Os}$, and $\mathrm{Ru}$, the extreme fractionation required to generate these different trends is difficult to reconcile with sulfide-silicate partitioning from a common parental magma (e.g., Fleet et al. 1996; Fleet et al. 1999; Sattari et al. 2002; Mungall and Brenan 2014).

\section{Relationship to the Skaergaard intrusion}

The PGE-bearing cumulate is structurally and mineralogically similar to lithologies within the Skaergaard intrusion. Although the cumulus mineral assemblage (cumulus olivine and intercumulus plagioclase) is at variance with the earliest formed Skaergaard cumulates (cumulus plagioclase and interstitial olivine, Maaløe 1976; Hoover 1989a), it is fair to say that our knowledge of the MBS at the base of the intrusion is limited. The chilled margin is variable in texture and composition (Hoover 1989a), and it is likely that heterogeneity could lead to local variations in the cumulus mineral assemblages. Localized fluctuations in the $\mathrm{SiO}_{2}$ activity, caused, for example, by contamination, could explain the anomalous occurrence of orthopyroxene. Recent research by Holness et al. (2015) demonstrated that the Skaergaard magma was emplaced in multiple injections during the evolution of the lowermost cumulates, and it would be reasonable to assume that several of these magmas could also have contributed to the compositional variability of the chilled margin.

We initially entertained the idea that the cumulate might represent a previously unknown source region for the picrite blocks in the Marginal Border Series. However, although the modal proportions of minerals are very similar to these blocks, the cumulus assemblages are different and the composition of cumulus olivine is significantly more evolved and variable in the PGE-bearing cumulate. We found no evidence for sulfide equilibration in olivine within the picrite blocks to suggest a connection with the PGE-bearing cumulate.

Olivine compositions within the PGE-bearing cumulate closely match the most primitive olivine in the Skaergaard cumulates $\left(\mathrm{Fo}_{74}\right.$, Hoover 1989b). As expected from the interstitial habit, plagioclase is more evolved than the equivalent cumulus plagioclase in the Layered Series. Olivine in parts of the MBS are clearly Ni depleted, suggesting that sulfide saturation at least locally affected the marginal parts of the intrusion. 


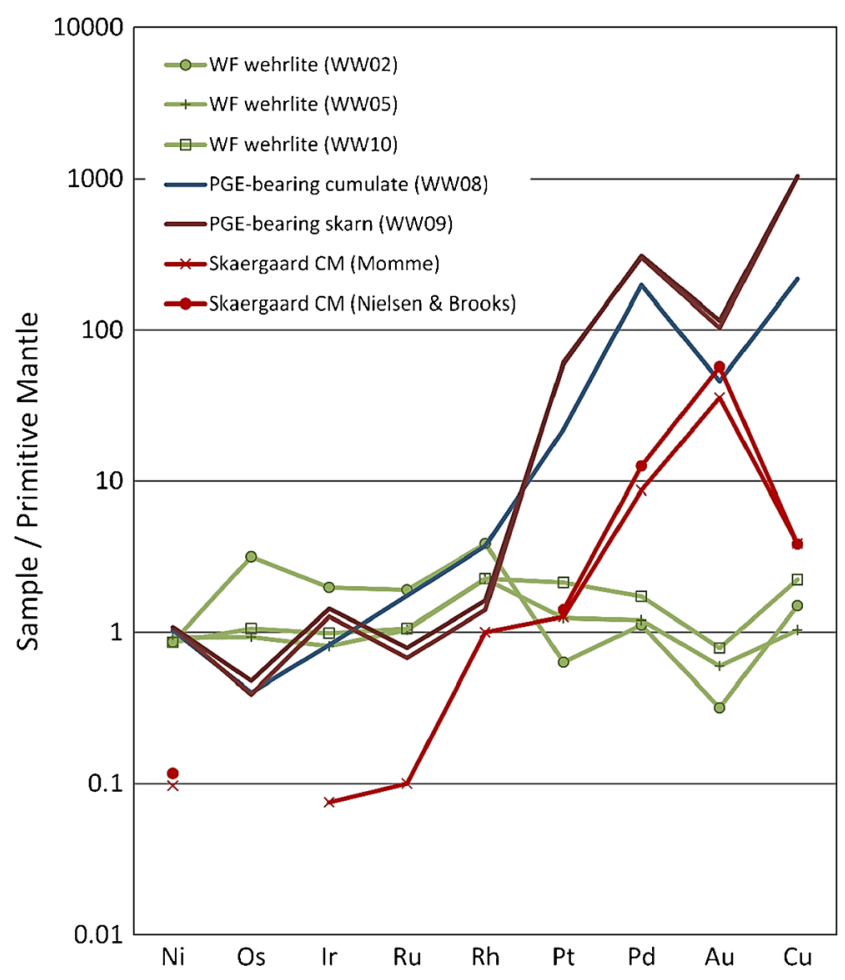

Fig. 9 Primitive mantle-normalized concentrations (normalization values from McDonough and Sun 1995) from the PGE occurrences, the Skaergaard chilled margin (data from Nielsen and Brooks 1995 and Momme 2000) and the Watkins Fjord wehrlite plug

The crescumulates and leucogabbroic blocks are further indications that the cumulate formed from evolved magma in a relatively dynamic magma chamber. The crescumulates evolve from feldspathic bases and appear to be controlled by the upward growth of plagioclase. In this respect, they are similar to the perpendicular feldspar rock in the Marginal Border Series (Wager and Deer 1939). Similar crescumulates have also been found among the picrite blocks (M. Holness, personal communication, 2012).

The leucogabbroic blocks are not unlike those found in the Skaergaard Layered Series (Irvine et al. 1998), and they demonstrate that the parental magma at some point was in contact with earlier formed, differentiated cumulates; that these cumulates were partially disrupted; and that a pathway existed for the blocks to become incorporated into the cumulate. This again suggests a connection to a relatively large magma chamber that was compositionally more evolved than the Watkins Fjord wehrlite plug.

A further indication of a Skaergaard connection comes from the PGE geochemistry, with both occurrences displaying strongly positive mantle-normalized PGE trends that parallel those of Skaergaard chilled margin (Fig. 9). These trends contrast strongly to the unfractionated PGE in the Watkins Fjord wehrlite. The PGEs are systematically enriched by $10-50$ times. The strongest enrichments are in Pt and Pd, but the IrPt-Pd ratios remain within the variability of the chilled margin.
The deviations in $\mathrm{Cu} / \mathrm{Pd}, \mathrm{Ni} / \mathrm{Cu}$, and $\mathrm{Pd} / \mathrm{Au}$ can be explained by variability in $\mathrm{Au}$ and $\mathrm{Cu}$ within the chilled margin (as also reported by Nielsen and Brooks 1995; Momme 2000).

\section{Formation of PGE-bearing schist}

The Precambrian basement represents a succession of highgrade metamorphic rocks. Kays et al. (1989) estimated the peak metamorphic conditions to have reached or exceeded 650-700 ${ }^{\circ} \mathrm{C}$ and 3-4 kbar. The coexistence of plagioclase and clinopyroxene (upper amphibolite to granulite facies) with biotite and actinolite (greenschist to lower amphibolite facies) in the schist indicates a fluid-assisted retrograde modification of the high-grade protolith. Apart from differences in the modal abundances, the sulfide and PGM assemblages are identical to the PGE-bearing cumulate, and we consider it unlikely that they formed independently as an integral part of the metamorphic basement.

Magmatic sulfide liquids have been demonstrated elsewhere to migrate into and interact with basement lithologies. A particularly interesting analog is the Kilvenjärvi deposit of the Portimo complex in Finland, where high concentrations of PGE are associated with sulfide more than $50 \mathrm{~m}$ below the base of the host intrusion (Iljina 1994; Andersen et al. 2006). This particular deposit appears to have formed by downward migration of sulfide liquid away from the host intrusion and subsequent equilibration with the host rocks (Iljina 1994; Andersen et al. 2006). Other examples include the PGEbearing skarns beneath the Platreef (Armitage et al. 2002), the Ngala Hill in Malawi (Henckel and Mitchell 2002), and the Talnakh area of Noril'sk (Ryabov et al. 1996).

We suggest that the schist developed by contact metasomatism as a batch of the Skaergaard parental magma came into contact with the basement lithologies. Assimilation of silicic basement could have locally reduced the capacity of the magma to carry sulfide, leading to silicate-sulfide immiscibility. Sulfide liquid could have ponded at the base of the magma and been locally expelled into the host rocks. The abundance of biotite in the schist suggests that the process might have been somewhat fluid assisted. However, as hydrous fluids would be expected to precipitate Cl-rich apatite (e.g., Boudreau et al. 1986), the F-rich composition of the apatite suggests that fluids were not a principal agent of mineralization.

\section{Process of mineralization}

Platinum-group element deposits at the margins of layered mafic-ultramafic complexes are of global economic interest. The Platreef alone hosts nearly $17 \mathrm{wt} \%$ of the PGE resources in the Bushveld complex, South Africa (Cawthorn 1999), and significant prospects have been documented from the Portimo and Koillismaa complexes, Finland, and the Coldwell 
complex and the East Bull Lake intrusive suite, Canada (Iljina and Lee 2005).

The sulfide assemblages are typical for orthomagmatic sulfides formed from mafic-ultramafic magmas, and the strong associations between the sulfides and the PGM indicate that the PGEs were collected by magmatic sulfide liquids. Nickel depletion in olivine from the PGE-bearing gabbro suggests that the sulfide formed directly from the local cumulate.

The sulfide and PGM assemblages of both occurrences are very similar, despite the very different host lithologies. Although the PGMs in the schist have a stronger association with hydrous silicates (Fig. 8), the sulfide association still dominates. The lack of variation between the PGM assemblages suggests that this association reflects the greater modal abundance of these minerals rather than a hydrothermal component to the PGE mineralization. The high $\mathrm{F} /(\mathrm{F}+\mathrm{Cl})$ indicates that associated apatite crystallized under relatively anhydrous conditions, which could be either directly from the parental magma or as part of the high-grade metamorphic host (cf., Spear and Pyle 2002). Magmatic-derived hydrous fluids would be expected to precipitate Cl-rich apatite instead (Boudreau and McCallum 1992). The near constant Ir-PtPd-Au ratios of the two occurrences confirm that the PGEs were largely unaffected by hydrothermal redistribution.

Differences within the relative abundances of pentlandite and chalcopyrite and in the PGE tenor between the occurrences imply that the sulfide melts formed as separate entities or that they were related through a process of fractionation. The abundance and distribution of sulfide in the gabbro suggest that it did not collect as a single liquid body but that at least some remained dispersed within the silicate magma or mush. Furthermore, the constant $\mathrm{Pd} / \mathrm{Ir}$ with variations in $\mathrm{Ni} /$ $\mathrm{Cu}$ is inconsistent with fractionation of monosulfide solid solution (e.g., Maier et al. 1998) from a relatively uniform sulfide body. Local variations in the silicate-sulfide mass ratios ( $R$ factors) during immiscibility can explain the variations in PGE tenor between the two occurrences. If the Skaergaard chilled margin is assumed to represent the primary magma, the total PGE concentrations indicate that the PGE-bearing cumulate formed with an $R$ factor around 210 and the schist 110 (Eq. 1).

The setting, mineralogy, and geochemistry of the occurrences are adequately explained by immiscibility in response to contamination (equivalent to the process documented for the Platreef by Holwell and McDonald 2006). Collection of the PGE by magmatic sulfide liquids in an environment with variable host rock assimilation can fully explain the mineralogical and geochemical variations in the sulfide. The retrograde assemblage of the schist is likely to have evolved through the interaction with the Skaergaard magma or associated magmatic fluids. However, the PGEs appear to have been passively carried in the sulfide liquid rather than directly interacted with contaminants or hydrous fluids.

\section{Comparison to the Platinova Reef}

Despite the geochemical similarities to the Skaergaard margin, it is notable that the sulfide minerals observed here are very different to sulfides that appear in the Platinova Reef and the upper parts of the Skaergaard Layered Series. The pyrrhotite + pentlandite + chalcopyrite assemblage is similar to traditional orthomagmatic sulfide deposits. The Skaergaard Layered Series, in contrast, is dominated by chalcopyrite, bornite, and digenite and has marcasite in the most fractionated parts. The pentlandite can be explained by early silicate-sulfide immiscibility during the crystallization of the marginal gabbros. During the formation of the Layered Series, in contrast, the Skaergaard magma had been almost completely depleted in Ni through olivine crystallization in the Hidden and Lower Zones prior to sulfide formation and therefore did not produce pentlandite. The differences between the chalcopyrite-pyrrhotite and chalcopyritebornite-digenite-marcasite assemblages can be explained by oxidation of the primary orthomagmatic sulfide assemblage in the
Fig. 10 Conceptual model for PGE mineralization along the northern margin of the Skaergaard intrusion. a Emplacement of olivine-phyric precursor to the Skaergaard intrusion. b Breakup of olivine-phyric precursor and country rocks during emplacement of the main Skaergaard evolved tholeiitic magma
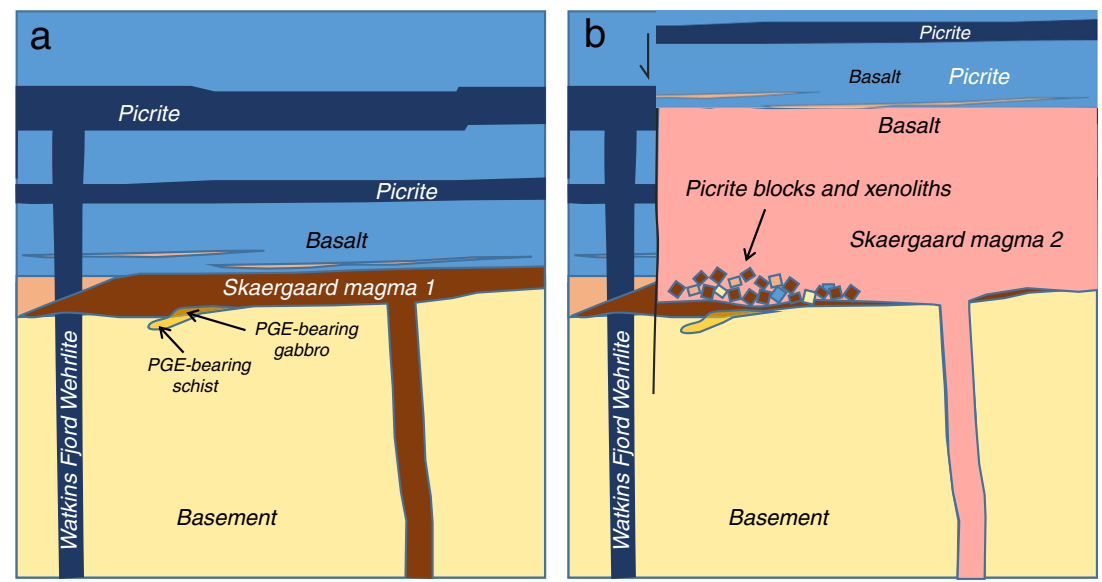
Layered Series (Andersen 2006) or by iron or oxygen exchange between sulfide and Fe-rich silicate melts (Nielsen et al. 2015).

\section{Implications for exploration}

The occurrence of PGE-bearing rocks along the margin of the Skaergaard intrusion indicates that contact-style mineralization should be considered as viable exploration targets for evolved tholeiitic intrusions. Significant potential could exist elsewhere along the margin of the Skaergaard intrusion. The discovery also raises the question whether other intrusions in East Greenland may have significant PGE-bearing sulfide concentrations along their margins, notably the much larger Kap Edvard Holm complex to the west where PGEs have been reported in the past (Bird et al. 1995; Arnason et al. 1997).

\section{Conclusions}

Two new occurrences of PGE immediately north of the Skaergaard intrusion most likely formed as the Skaergaard magma interacted with Precambrian gneiss at the base of the intrusion. Variable contamination as well as multiple magma injections contributed to inhomogeneity and led to localized silicate-sulfide immiscibility along the margin (Fig. 10). While sulfide was largely retained in the marginal gabbro, some of the sulfide liquid escaped the silicate magma to become incorporated into the metamorphic host rock. We cannot yet say if extensive mineralization took place along the intrusive contact, but the relatively low $R$ factors and high PGE tenors indicate that any sulfide-bearing rock associated with the Skaergaard margin may be of economic interest. The discoveries show that PGE mineralization in the Skaergaard intrusion was not restricted to the stratiform Platinova Reef. Mineralization also took place where contamination of the Skaergaard magma led to localized silicate-sulfide liquid immiscibility. The sulfide assemblage suggests that the Skaergaard parental magma formed pyrrhotite + pentlandite + chalcopyrite assemblages similar to most other mafic or ultramafic magmas and that it was driven to form bornite and digenite only through extreme differentiation. The new occurrences suggest that small, evolved layered intrusions may be far more prospective for PGE than previously thought.

Acknowledgements The authors are grateful for logistical support from Platina Resources Ltd., Geological Survey of Denmark and Greenland, and members of the 2011 Skaergaard field team. JCØA was supported by grants from Helford Geoscience LLP and the Camborne School of Mines Trust. CT was supported by the Danish Natural Research Council and the Carlsberg Foundation, and CEL was supported by the US National Science Foundation (EAR-1019887). Samples were sectioned and prepared by Steve Pendray at Camborne School of Mines. The QEMSCAN is a registered trade mark of FEI Corporation.
Open Access This article is distributed under the terms of the Creative Commons Attribution 4.0 International License (http:// creativecommons.org/licenses/by/4.0/), which permits unrestricted use, distribution, and reproduction in any medium, provided you give appropriate credit to the original author(s) and the source, provide a link to the Creative Commons license, and indicate if changes were made.

\section{References}

Andersen JCØ (2006) Postmagmatic sulphur loss in the Skaergaard Intrusion: implications for the formation of the Platinova Reef. Lithos 92:198-221

Andersen JCØ, Rasmussen H, Nielsen TFD, Rønsbo JG (1998) The triple group and the Platinova gold and palladium reefs in the Skaergaard intrusion: stratigraphic and petrographic relations. Econ Geol 93: 488-509

Andersen JCØ, Power MR, Momme P (2002) Platinum-group elements in the Palaeogene North Atlantic igneous province. In: Cabri LJ (ed) The geology, geochemistry, mineralogy, and mineral beneficiation of platinum-group elements, vol 54. Canadian Institute of Mining, Metallurgy, and Petroleum. CIM, Montréal, pp. 637-667

Andersen JCØ, Thalhammer OAR, Schoenberg R (2006) Platinum-group element and Re-Os isotope variations of the high-grade Kilvenjärvi platinum-group element deposit, Portimo layered igneous complex, Finland. Econ Geol 101:159-177

Armitage PEB, McDonald I, Edwards SJ, Manby GM (2002) Platinumgroup element mineralization in the Platreef and calc-silicate footwall at Sandsloot, Potgietersrus district, South Africa. Trans Inst Min Metallurgy 111:B36-B45

Armstrong JT (1995) CITZAF: a package of correction programs for the quantitative electron microbeam X-ray analysis of thick polished materials, thin films, and particles. Microbeam Analysis 4:177-200

Arnason JG (1995) Gold and platinum-group element mineralization in tertiary mafic intrusions of East Greenland. Dissertation, Stanford University, pp 197

Arnason JG, Bird DK (2000) A gold- and platinum mineralized layer in gabbros of the Kap Edvard Holm Complex: field, petrologic, and geochemical relations. Econ Geol 95:945-970

Arnason JG, Bird DK, Bernstein S, Kelemen PB (1997) Gold and platinum-group element mineralization in the Kruuse Fjord gabbro complex, East Greenland. Econ Geol 92:490-501

Bird DK, Brooks CK, Gannicott RA, Turner PA (1991) A gold-bearing horizon in the Skaergaard intrusion, East Greenland. Econ Geol 86: 1083-1092

Bird DK, Arnason JG, Brandriss ME, Nevle RJ, Radford G, Bernstein S, Gannicott RA, Kelemen PB (1995) A gold-bearing horizon in the Kap Edvard Holm complex, East Greenland. Econ Geol 90:1288-1300

Boudreau AE, McCallum IS (1992) Concentration of platinum group elements by magmatic fluids in layered intrusions. Econ Geol 87: $1830-1848$

Boudreau AE, Mathez EA, McCallum IS (1986) Halogen geochemistry of the Stillwater and Bushveld complexes: evidence for transport of the platinum-group elements by Cl-rich fluids. J Petrol 27:967-986

Brenan JM (2003) Effects of fO2, fS2, temperature, and melt composition on Fe-Ni exchange between olivine and sulfide liquid: implications for natural olivine-sulfide assemblages. Geochim Cosmochim Acta 67:2663-2681

Cawthorn RG (1999) The platinum and palladium resources of the Bushveld complex. S Afr J Sci 95:481-489

Fleet ME, MacRae ND, Osborne MD (1981) The partition of nickel between olivine, magma and immiscible sulfide liquid. Chem Geol 32:119-127

Fleet ME, Crocket JH, Stone WE (1996) Partitioning of platinum-group elements (Os, Ir, Ru, Pt, Pd) and gold between sulfide liquid and basalt melt. Geochim Cosmochim Acta 60:2397-2412 
Fleet ME, Crocket JH, Liu M, Stone WE (1999) Laboratory partitioning of platinum-group elements (PGE) and gold with application to magmatic sulfide-PGE deposits. Lithos 47:127-142

Gottlieb P, Wilkie G, Sutherland D, Ho-Tun E, Suthers S, Perera K, Jenkins B, Spencer S, Butcher A, Rayner J (2000) Using quantitative electron microscopy for process mineralogy applications. JOM April 2000:24-25

Henckel J, Mitchell AA (2002) The Ngala Hill PGE-skarn (Southern Malawi) In: Boudreau AE (ed) 9th Int Platinum Symp Abst. pp 179-180

Holm PM (1991) Radiometric age determinations in the Kærven area, Kangerdlugssuaq, East Greenland Tertiary igneous province: ${ }^{40} \mathrm{Ar} /{ }^{39} \mathrm{Ar}, \mathrm{K} / \mathrm{Ar}$ and $\mathrm{Rb} / \mathrm{Sr}$ isotopic results. Bull Geol Soc Denmark 38:183-201

Holness MB, Tegner C, Namur O, Pilbeam L (2015) The earliest history of the Skaergaard magma chamber: a textural and geochemical study of the Cambridge drill core. J Petrol 56:1199-1227

Holwell DA, Keays RR (2014) The formation of low-volume, high-tenor magmatic PGE-Au sulfide mineralization in closed systems: evidence from precious and base metal geochemistry of the Platinova Reef, Skaergaard Intrusion, East Greenland. Econ Geol 109:387-406

Holwell D, McDonald I (2006) Petrology, geochemistry and the mechanisms determining the distribution of platinum-group element and base metal sulphide mineralisation in the Platreef at Overysel, northern Bushveld complex, South Africa. Mineral Deposita 41:575-598

Holwell D, Abraham-James T, Keays R, Boyce A (2012) The nature and genesis of marginal $\mathrm{Cu}-\mathrm{PGE}-\mathrm{Au}$ sulphide mineralisation in Paleogene macrodykes of the Kangerlussuaq region, East Greenland. Mineral Deposita 47:3-21

Hoover JD (1989a) The chilled marginal gabbro and other contact rocks of the Skaergaard Intrusion. J Petrol 30:441-476

Hoover JD (1989b) Petrology of the Marginal Border Series of the Skaergaard Intrusion. J Petrol 30:399-439

Huber H, Koeberl C, McDonald I, Reimold WU (2001) Geochemistry and petrology of Witwatersrand and Dwyka diamictites from South Africa: search for an extraterrestrial component. Geochim Cosmochim Acta 65:2007-2016

Iljina M (1994) The Portimo layered igneous complex. Acta Universitatis Ouluensis, series A 258:1-158

Iljina MJ, Lee CA (2005) PGE deposits in the marginal series of layered intrusions. In: Mungall JE (ed) Exploration for platinum-group element deposits. Mineral Assoc Canada Short Course Series, Ottawa, pp. 75-96

Irvine TN, Andersen JCØ, Brooks CK (1998) Included blocks (and blocks within blocks) in the Skaergaard Intrusion: geological relations and the origins of rhythmic modally graded layers. Geol Soc Am Bull 110:1398-1447

Kays MA, McBirney AR (1982) Origin of picrite blocks in the Marginal Border Group of the Skaergaard Intrusion, East Greenland. Geochim Cosmochim Acta 46:23-30

Kays MA, Goles GG, Grover TW (1989) Precambrian sequence bordering the Skaergaard intrusion. J Petrol 30:321-361

Lindsley DH, Brown GM, Muir ID (1969) Conditions of the ferrowollastonite-ferohedenbergite inversion in the Skaergaard intrusion, East Greenland. Miner Soc Am Special Paper 2:193-201

Maaløe S (1976) The zoned plagioclase of the Skaergaard Intrusion, East Greenland. J Petrol 17:398-419

Maier WD, Barnes S-J, de Waal SA (1998) Exploration for magmatic Ni$\mathrm{Cu}$-PGE sulphide deposits: a review of some recent advances in the use of geochemical tools, and their application to some South African ores. S Afr J Geol 101:237-253

McBirney AR (1989) Geological map of the Skaergaard intrusion, East Greenland, $1: 20000$ University of Oregon

McDonough WF, Sun S-S (1995) The composition of the Earth. Chem Geol 120:223-253
Miller JD, Jr., Andersen JCØ (2002) Attributes of Skaergaard-type PGE reefs In: Boudreau AE (ed) 9th Int Platinum Symp Abst. pp 305-308

Momme P (2000) Flood basalt generation and differentiation: PGEgeochemistry of East Greenland flood basalts, comagmatic intrusions and comparison with Sibirian flood basalts. Dissertation, Aarhus University, pp 153

Momme P, Tegner C, Brooks CK, Keays RR (2002) The behaviour of platinum-group elements in basalts from the East Greenland rifted margin. Contrib Mineral Petrol 143:133-153

Mungall JE, Brenan JM (2014) Partitioning of platinum-group elements and $\mathrm{Au}$ between sulfide liquid and basalt and the origins of mantlecrust fractionation of the chalcophile elements. Geochim Cosmochim Acta 125:265-289

Nielsen TFD, Brooks CK (1981) The E Greenland rifted continental margin: an examination of the coastal flexure. J Geol Soc Lond 138:559-568

Nielsen TFD, Brooks CK (1995) Precious metals in magmas of East Greenland: factors important to the mineralization in the Skaergaard Intrusion. Econ Geol 90:1911-1917

Nielsen TFD, Andersen JCØ, Holness MB, Keiding JK, Rudashevsky NS, Rudashevsky VN, Salmonsen LP, Tegner C, Veksler IV (2015) The Skaergaard PGE and gold deposit: the result of in situ fractionation, sulphide saturation, and magma chamber-scale precious metal redistribution by immiscible Fe-rich melt. J Petrol 56:1643-1676

Park B-J, Jang Y-D, Choo C-O, Lee I, Kim J-J (2010) Trace element variation in olivine in the Skaergaard intrusion: petrologic implications. Geosciences J 14:345-358

Pirrie D, Butcher AR, Power MR, Gottlieb P, Miller GL (2004) Rapid quantitative mineral and phase analysis using automated scanning electron microscopy (QemSCAN); potential applications in forensic geoscience In: Pye K, Croft DJ (eds) Forensic geoscience, principles, techniques and applications. Geol Soc London Spec Publ, pp 123-136

Platina Resources Ltd (2008) Skaergaard project, East Greenland. ASX announcement, 28 February 2008

Prendergast MD (2000) Layering and precious metals mineralization in the Rincón del Tigre Complex, Eastern Bolivia. Econ Geol 95:113-130

Rudashevsky NS, Garuti G, Andersen JCØ, Kretser YL, Rudashevsky VN, Zaccarini F (2002) Separation of accessory minerals from rocks and ores by hydroseparation (HS) technology: method and application to CHR-2 chromitite, Niquelândia intrusion, Brazil. Trans Inst Min Metallurgy B 111:B87-B94

Ryabov VV, Shevko AY, Simonov ON, Anoshin GN (1996) Composition of the platinum-bearing chromium-rich skarns of Talnakh (Noril'sk region). Russ Geol Geophys 37:60-75

Sattari P, Brenan JM, Horn I, McDonough WF (2002) Experimental constraints on the sulfide- and chromite-silicate melt partitioning behavior of rhenium and platinum-group elements. Econ Geol 97:385-398

Spear FS, Pyle JM (2002) Apatite, monazite and xenotime in metamorphic rocks. Rev Mineral Geochem 48:293-335

Stewart BW, DePaolo DJ (1990) Isotopic studies of processes in mafic magma chambers: II. The Skaergaard intrusion, East Greenland. Contrib Mineral Petrol 104:125-141

Wager LR, Brown GM (1968) Layered igneous rocks. Oliver \& Boyd, Edinburgh and London

Wager LR, Deer WA (1939) Geological investigations in East Greenland, part III. The petrology of the Skaergaard intrusion, Kangerdlugssuaq, East Greenland. Medd Grønland 105:1-352

Whitney DL, Evans BW (2010) Abbreviations for names of rock-forming minerals. Amer Mineral 95:185-187

Wotzlaw J-F, Bindeman IN, Schaltegger U, Brooks CK, Naslund HR (2012) High-resolution insights into episodes of crystallization, hydrothermal alteration and remelting in the Skaergaard intrusive complex. Earth Planet Sci Lett 355-356:199-212 